\title{
Cytotoxic Activities of Cymbopogon citratus Extracts against Three Different Human Cancer Cell Lines: Lung Carcinoma (A549), Breast Cancer (MCF-7) and Hepatocellular Carcinoma (Hep G2)
}

\author{
Heba K. Sayed ${ }^{*}$, Mohammady A. Issa ${ }^{2}$, Magda E. Mahmoud ${ }^{2}$, \\ Hamadi A. Ismail ${ }^{2}$, Emad A. Hassan ${ }^{1}$, and Ahmed G. Darwish ${ }^{2}$ \\ ${ }^{1}$ Central Lab of Organic Agriculture. Agri. Res. Center. \\ ${ }^{2}$ Department of Biochemistry, Faculty of Agriculture, Minia University, Minia 61519, Egypt. \\ *Corresponding author: hebakenawy85@yahoo.com; Tel: + 01007827641.
}

\section{Article information}

Received: 11 August 2021

Revised: 2 October 2021

Accepted: 10 October 2021

\section{Key words}

Cymbopogon citratus

Lemon grass

A549

HepG2

MCF- 7.

\begin{abstract}
Cymbopogon citratus, commonly known as Lemon grass is a small herbaceous plant of the Poaceae family. It is used as traditional medicine for the treatment of numerous diseases such as cancer, fever, sore throats, cough, laryngitis, bronchitis, body ache, headache, digestive problems, etc. This study deals with the cytotoxic activities of $C$. citratus against three different human cancer cells A549, HepG2, and MCF-7. The chemical fractionation of the plant material using ethanol, ethyl acetate, and hexane was prepared and analyzed for bioactivity. Ethyl acetate extract showed the highest anticancer activity against A549, HepG2, and MCF-7 human cancer cells with cell viability percentage $\left(64.09 \pm 1.11,41.22 \pm 0.34\right.$, and $66.24 \pm 1.50 \%$, respectively) with $\mathrm{IC}_{50}$ values $(147,65$, and $155 \mu \mathrm{g} / \mathrm{ml}$, respectively). Results of this study show that the ethyl acetate fraction of $C$. citratus is a rich source of phenolics and other compounds that can play a significant role in preventing the progression of cancer diseases.
\end{abstract}

\section{Introduction}

Lemon grass (Cymbopogon citratus) is commonly used in folk alternative medicine to treat a number of ailments. Citral, an acyclic monoterpene aldehyde, has been discovered as one of the bioactive compounds found in $\mathrm{C}$. citratus. Citral has been discovered as the plant's most important bioactive component, accounting for the majority of the plant's bioactivity. [1] such as antimutagenic [2], antiproliferative [3], antinociceptive [4], and antiparasitic effects against leishmaniasis properties [5, 6]. This plant's aqueous drink, known in Portuguese as "abafado," was supposed to have potent anti-neurological and antigastrointestinal properties [7]. It's also known to be a good scavenger of free radicals and reactive oxygen species (ROS). Because of its high ability for free radical scavenging and antioxidation, researchers looked at the effects of C. citratus ethanolic extract on the proliferation and cell development of various human cancer cell lines [8].

Cancer is the leading cause of death in the majority of countries around the world. Cell proliferation that is unaffected by growth factor regulation, as well as apoptosis resistance and angiogenesis, are all hallmarks of cancer, resulting in a disruption of homeostatic circumstances and carcinogenesis. Several organs, including the brain, liver, lungs, kidney, breast, bones, and ovaries, are affected by various cancers [9]. Hepatocellular carcinoma (HCC), also known as malignant hepatoma, is a genetically and phenotypically heterogeneous tumour that shows the etiological factors that lead to the development of HCC [10]. An oxidative stress environment is created by cancer. Antioxidants have been found to reduce stress by scavenging reactive oxygen species (ROS) and activating the DNA repair process[11].

After liver cancer, lung carcinoma is the second most fatal malignancy. [12], As well as being the leading cause of cancerrelated deaths. Every year, 22,000 people in Vietnam are diagnosed with lung cancer, with 19,500 people dying as a result. Carcinomas or tumours formed from epithelial lineage altered cells account for about 98 percent of lung malignancies. There are about four dozen distinct histological variants of lung cancer that have lately been discovered. The two most frequent types of lung cancer, small cell lung cancer and non-small cell lung cancer, account for around 85 percent of all lung cancer cases. Natural commodities have an unequalled chemical diversity, making them excellent for the development of novel medicines. Folk medicine is utilised by more than $80 \%$ of the world's population for primary healthcare, according to the World Health Organization. Medicinal plants have been discovered to have novel anti-cancer drugs. Several herbal drugs have been used for cancer treatment for thousands of years because of their traditional acceptability and minimal adverse effects [13].

Breast cancer is described as the uncontrolled spread of malignant tissue within the breast that must be surgically removed because if it spreads too far, it can lead to death. Breast tumours are characterised as channel, lobular, or inflammatory structures depending on where they originate, Several early indications of breast cancer include persistent nipple discharge and inversion of the nipples. Natural-derived chemicals are increasingly the focus of scientific research since they have 
fewer hazardous side effects than existing treatments like chemotherapy [14].

Hepatocellular carcinoma (HCC) is the most common primary liver cancer and one of the most widely distributed malignancies worldwide, with an ever-increasing prevalence over the last decade. [15]. HCC is a preventative disease rather than a curable one, because to the lack of appropriate treatment. Future study should focus on the usage of several plants that are thought to be rich sources of physiologically active chemicals [16]. The purpose of this study was to assess the cytotoxic activities of several C. citratus plant fractions.

\section{Materials and Methods}

\subsection{Plant sample collection and preparation of extracts}

The leaf of $C$. citratus was collected from the experimental farm, Fac. of Agric. Minia University. The fresh and healthy leaf was cleaned carefully and rinsed well with running tap water and air dried, away from the sun, at ambient condition for 4 weeks and ground with an electric grinder to a fine powder. The powdered leaf was kept in a sealed container at ambient conditions. One hundred grams of powdered sample was transferred into the round bottom flask $(1000 \mathrm{~mL})$ mixed with a magnetic stirrer and $700 \mathrm{~mL}$ solvents $(80 \%$ ethanol, ethyl acetate and hexane) added with constant stirring for $6 \mathrm{hrs}$. at ambient conditions. The extract was then collected and filtered off using Whatman No.1 filter paper. The supernatant was dried using a rotary evaporator and speed vacuum. Then stored at $4^{\circ} \mathrm{C}$. $10 \mathrm{mg} / \mathrm{ml}$ dimethyl sulfoxide (DMSO) was dissolved for further analysis modified [17].

\subsection{Cell culture and reagents}

Breast cancer (MCF-7) cell, Lung carcinoma (A549) and Hepatocellular carcinoma (HepG2) were obtained from Nawah Scientific Inc., (Mokatam, Cairo, Egypt). Cells were maintained in DMEM media supplemented with $100 \mathrm{mg} / \mathrm{mL}$ of streptomycin, 100 units $/ \mathrm{mL}$ of penicillin, and $10 \%$ of heatinactivated fetal bovine serum in humidified, $5 \%$ (v/v) $\mathrm{CO}_{2}$ atmosphere at $37^{\circ} \mathrm{C}$.

\subsection{Cytotoxicity assay}

Cell viability was assessed by SRB assay. Aliquots of $100 \mu \mathrm{L}$ cell suspension $\left(5 \times 10^{3}\right.$ cells $)$ were in 96-well plates and incubated in complete media for $24 \mathrm{~h}$. Cells were treated with $100 \mu \mathrm{L}$ media containing plant extracts at numerous concentrations. After $72 \mathrm{~h}$ of adding extracts, cells were fixed by replacing media with $150 \mu \mathrm{L}$ of $10 \%$ TCA and incubated at $4^{\circ} \mathrm{C}$ for $1 \mathrm{~h}$. The TCA solution was removed, and the cells were washed 5 times with distilled water. Aliquots of $70 \mu \mathrm{L}$ SRB solution $(0.4 \% \mathrm{w} / \mathrm{v})$ were added and incubated in a dark place at room temperature for $10 \mathrm{~min}$. Plates were washed 3 times with $1 \%$ acetic acid and allowed to air-dry overnight. Then, 150 $\mu \mathrm{L}$ of TRIS $(10 \mathrm{mM})$ was added to dissolve the protein-bound SRB stain; the absorbance was measured at $540 \mathrm{~nm}$ using a BMG LABTECH®- FLUOstar Omega microplate reader (Ortenberg, Germany) [18,19].

\section{Results and Discussion}

3.1. Cytotoxic activity of Cymbopogon citratus extracts against HepG2, A549 and MCF-7 human cancer cells.

Cytotoxicity of Cymbopogon citratus extracts was tested on pulmonary cancer (A549), hepatocellular carcinoma (HepG2), and Breast cancer (MCF-7) cells. All the extracts (ethanol, ethyl acetate, and hexane) of c. citratus exhibited significant $(\mathrm{p}<0.005)$ cytotoxicity against the cancer cells tested. Ethanol extract consistently showed higher cytotoxicity levels in all cells when compared to the other extracts.

\subsubsection{Effect of $\boldsymbol{C}$. citratus on HepG2 Cell Viability.}

Liver cancer (Hep G2) cell viability was determined by using sulforhodamine B ( SRB) assay and compared with untreated cells as a control. The results showed that in (table 1) the viability of HepG2 cells significantly decreased by increasing the ethyl acetate extract of $C$. citratus concentrations with $\mathrm{IC}_{50}$ $65 \mu \mathrm{g} / \mathrm{ml}$ compared to other fractions (Fig. 1). The viability percentage of $C$. citratus ethanol $80 \%$, ethyl acetate and hexane on liver cancer (HepG2) cell lines were $89.80 \%, 86.73 \%$ and $89.64 \%$ at $10 \mu \mathrm{g} / \mathrm{ml}$, respectively. While the viability percentage of $C$. citratus ethanol $80 \%$, ethyl acetate and hexane on liver cancer (HepG2) cell lines were $86.55 \% 41.22 \%$ and $71.72 \%$ at $100 \mu \mathrm{g} / \mathrm{ml}$, respectively. But the viability percentage of $C$. citratus ethanol $80 \%$, ethyl acetate and hexane on liver cancer (HepG2) cell lines were $2.09 \%, 3.86 \%$ and $12.03 \%$ at $1000 \mu \mathrm{g} / \mathrm{ml}$, respectively.

Table (1): Percentage Cell Viability and $\mathrm{IC}_{50}$ of Ethanol $80 \%$, Ethyl acetate, and Hexane extracts of $C$. citratus against HepG2 cell line.

\begin{tabular}{|c|c|c|c|}
\hline Plant extract & $\begin{array}{c}\text { Concentration } \\
(\mu \mathrm{g} / \mathrm{ml})\end{array}$ & $\begin{array}{c}\text { Cell viability } \\
\%\end{array}$ & $\begin{array}{c}\mathrm{IC}_{50} \\
(\mu \mathrm{g} / \mathrm{ml})\end{array}$ \\
\hline \multirow[t]{3}{*}{ Ethanol 80\% } & 10 & $89.80 \pm 0.28$ & \multirow{3}{*}{215} \\
\hline & 100 & $86.55 \pm 0.57$ & \\
\hline & 1000 & $2.09 \pm 0.80$ & \\
\hline \multirow[t]{3}{*}{ Ethyl acetate } & 10 & $86.73 \pm 0.20$ & \multirow{3}{*}{65} \\
\hline & 100 & $41.22 \pm 0.34$ & \\
\hline & 1000 & $3.86 \pm 0.83$ & \\
\hline \multirow[t]{3}{*}{ Hexane } & 10 & $89.64 \pm 0.35$ & \multirow{3}{*}{218} \\
\hline & 100 & $71.72 \pm 1.04$ & \\
\hline & 1000 & $12.03 \pm 1.00$ & \\
\hline
\end{tabular}

The data were expressed as mean $\pm \mathrm{SD}$ of separated triplicate experiments. $\mathrm{IC}_{50}$ : the half-maximal inhibitory concentration is a measure of the effectiveness of a compound in inhibiting biological or biochemical function. Ethanol, Ethyl acetate and Hexane.

\subsubsection{Effect of $C$. citratus on A549 cell viability.}

Lung cancer (A549) cell viability was determined by using SRB assay and compared with untreated cells as a control. The results showed that in ( table 2) the viability of A549 cells significantly decreased by increasing the ethyl acetate extract of C. citratus concentrations with $\mathrm{IC}_{50} 147 \mu \mathrm{g} / \mathrm{ml}$ compared to 
other fractions (Fig2). The viability percentage of $C$. citratus ethanol $80 \%$, ethyl acetate and hexane on lung cancer (A549) cell lines were $95.26 \%, 97.3 \%$ and $94.51 \%$ at $10 \mu \mathrm{g} / \mathrm{ml}$, respectively. While the viability percentage of $C$. citratus ethanol $80 \%$, ethyl acetate and hexane on lung cancer (A549) cell lines were $72.34 \%, 64.09 \%$ and $70.58 \%$ at $100 \mu \mathrm{g} / \mathrm{ml}$, respectively. But the viability percentage of $C$. citratus ethanol $80 \%$, ethyl acetate and hexane on lung cancer (A549) cell lines were $1.84 \%, 12.47 \%$ and $33.44 \%$ at $1000 \mu \mathrm{g} / \mathrm{ml}$, respectively

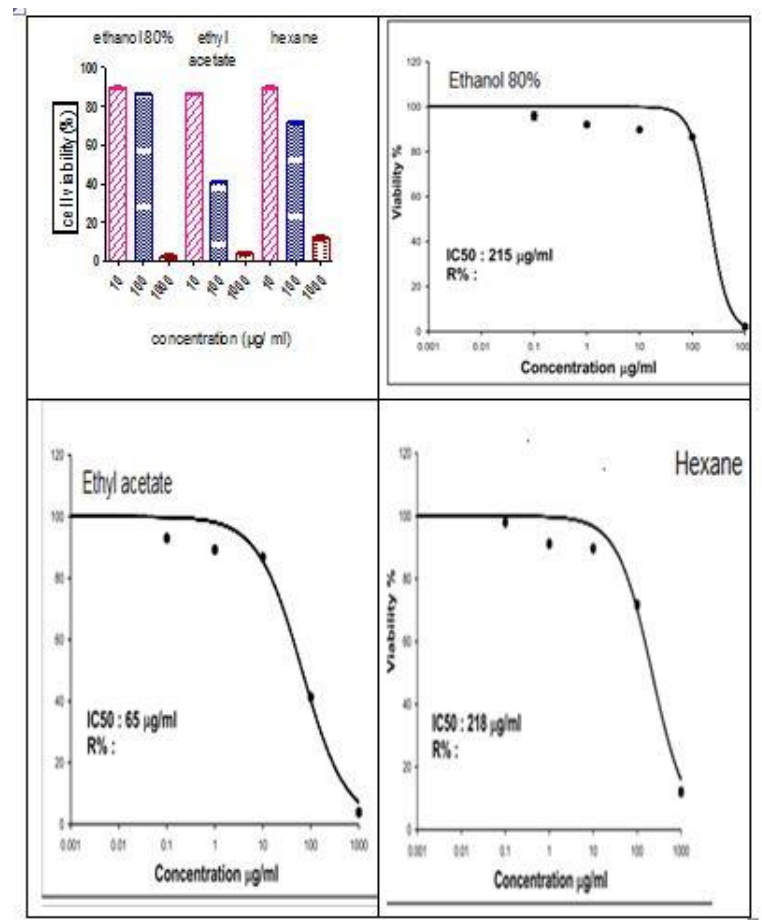

Figure 1: Effect of C. citratus extracts (Ethanol, Ethyl acetate and Hexane) on human liver cancer (HepG2) cell viability by the SRB assay. The data were expressed as Mean \pm SD of separated triplicate experiments.

Table (2): Percentage Cell Viability and $\mathrm{IC}_{50}$ of Ethanol $80 \%$, Ethyl acetate, and Hexane extracts of $C$. citratus against A549 cell line.

\begin{tabular}{|c|c|c|c|}
\hline Plant extract & $\begin{array}{c}\text { Concentration } \\
(\mu \mathrm{g} / \mathrm{ml})\end{array}$ & Cell viability \% & $\begin{array}{c}\mathrm{IC}_{50} \\
(\mu \mathrm{g} / \mathrm{ml})\end{array}$ \\
\hline \multirow[t]{3}{*}{ Ethanol 80\% } & 10 & $95.26 \pm 0.32$ & \multirow{3}{*}{162} \\
\hline & 100 & $72.34 \pm 0.86$ & \\
\hline & 1000 & $1.84 \pm 0.26$ & \\
\hline \multirow[t]{3}{*}{ Ethyl acetate } & 10 & $97.3 \pm 0.19$ & \multirow{3}{*}{147} \\
\hline & 100 & $64.09 \pm 1.11$ & \\
\hline & 1000 & $12.47 \pm 0.43$ & \\
\hline \multirow[t]{3}{*}{ Hexane } & 10 & $94.51 \pm 0.13$ & \multirow{3}{*}{367} \\
\hline & 100 & $70.58 \pm 1.23$ & \\
\hline & 1000 & $33.44 \pm 1.33$ & \\
\hline
\end{tabular}

The data were expressed as mean $\pm \mathrm{SD}$ of separated triplicate experiments. IC50: the half-maximal inhibitory concentration is a measure of the effectiveness of a compound in inhibiting biological or biochemical function. Ethanol, Ethyl acetate and Hexane.

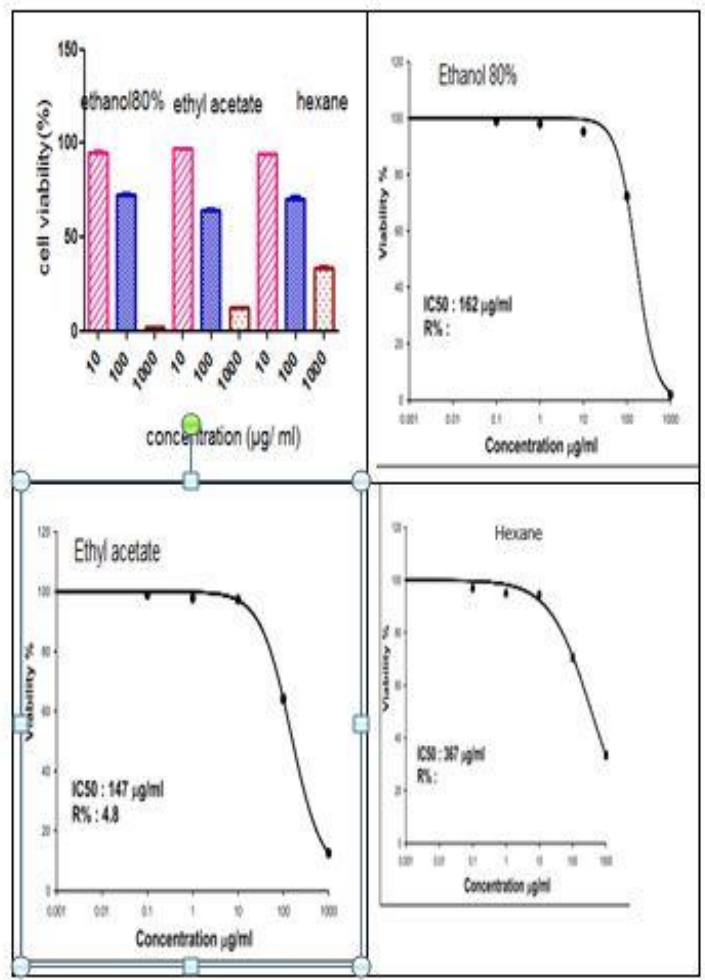

Figure 2: Effect of $C$. citratus extracts (Ethanol, Ethyl acetate and Hexane) on Human lung cancer(A549) cell viability by the SRB assay. The data were expressed as Mean \pm SD of separated triplicate experiments

\subsubsection{Effect of $C$. citratus on MCF-7 cell viability.}

Breast cancer (MCF-7 ) cell viability was determined by using SRB assay and compared with untreated cells as a control. The results showed that in (table 3) the viability of MCF-7 cells significantly decreased by increasing the ethyl acetate extract of C. citratus concentrations with $\mathrm{IC}_{50} 155 \mu \mathrm{g} / \mathrm{ml}$ compared to other fractions (Fig. 3). The viability percentage of $C$. citratus ethanol $80 \%$, ethyl acetate and hexane on breast cancer (MCF7) cell lines were $91.01 \%, 95.60 \%$ and $96.55 \%$ at $10 \mu \mathrm{g} / \mathrm{ml}$, respectively. While the viability percentage of $C$. citratus ethanol $80 \%$, ethyl acetate and hexane on breast cancer (MCF7) cell lines were $79.57 \%, 66.24 \%$ and $77.16 \%$ at $100 \mu \mathrm{g} / \mathrm{ml}$, respectively. But the viability percentage of $C$. citratus ethanol $80 \%$, ethyl acetate and hexane on breast cancer (MCF-7) cell lines were $31.28 \%, 5.021 \%$ and $15.14 \%$ at $1000 \mu \mathrm{g} / \mathrm{ml}$, respectively.

Table (3): Percentage cell viability and $\mathrm{IC}_{50}$ of Ethanol $80 \%$, Ethyl acetate, and Hexane extracts of $C$. citratus respectively on MCF-7 cell line

\begin{tabular}{|c|c|c|c|}
\hline Plant extract & $\begin{array}{c}\text { Concentration } \\
(\mu \mathrm{g} / \mathrm{ml})\end{array}$ & Cell viability \% & $\begin{array}{c}\mathrm{IC}_{50} \\
(\mu \mathrm{g} / \mathrm{ml})\end{array}$ \\
\hline Ethanol 80\% & 10 & $91.01 \pm 0.89$ & \multirow{2}{*}{172} \\
\cline { 2 - 3 } & 100 & $79.57 \pm 0.57$ & \\
\hline
\end{tabular}




\begin{tabular}{|c|c|c|c|}
\hline & 1000 & $31.28 \pm 0.78$ & \\
\hline Ethyl acetate & 10 & $95.60 \pm 0.08$ & \multirow{2}{*}{155} \\
\cline { 2 - 3 } & 100 & $66.24 \pm 1.50$ & \\
\cline { 2 - 3 } & 1000 & $5.021 \pm 0.28$ & \\
\hline \multirow{3}{*}{ Hexane } & 10 & $96.55 \pm 0.11$ & \multirow{2}{*}{258} \\
\cline { 2 - 3 } & 100 & $77.16 \pm 0.43$ & \\
\cline { 2 - 3 } & 1000 & $15.14 \pm 0.49$ & \\
\hline
\end{tabular}

The data were expressed as mean \pm SD of separated triplicate experiments. $\mathrm{IC}_{50}$ : the half-maximal inhibitory concentration is a measure of the effectiveness of a compound in inhibiting biological or biochemical function. Ethanol, Ethyl acetate and Hexane.

The results reported that depending on extraction solvent content, extract obtained from ethyl acetate solvent showed to be more potent on hepatocarcinoma cell line (IC50 $=65$ $\mu \mathrm{g} / \mathrm{mL}$ ), followed by ethanol fraction $\left(\mathrm{IC}_{50}=215 \mu \mathrm{g} / \mathrm{mL}\right.$ ), then hexane fraction with $\mathrm{IC}_{50}=219 \mu \mathrm{g} / \mathrm{Ml}$. On the other hand, ethyl acetate extract showed a moderate potency on MCF-7 cells having an $\mathrm{IC}_{50}$ of $155 \mu \mathrm{g} / \mathrm{mL}$ compare to untreated cells. Ethyl acetate fraction showed anticancer activity against A549 cells with $\mathrm{IC}_{50}=147 \mu \mathrm{g} / \mathrm{Ml}$. These results suggested antiproliferative efficacy of $C$. citratus ethyl acetate extract against human cancer cell lines may be related to the number of phenolics and flavonoids present in the ethyl acetate fraction would have contributed to the cytotoxic activity of cancer cells, but the current study could not determine the exact phytochemicals responsible for this activity.

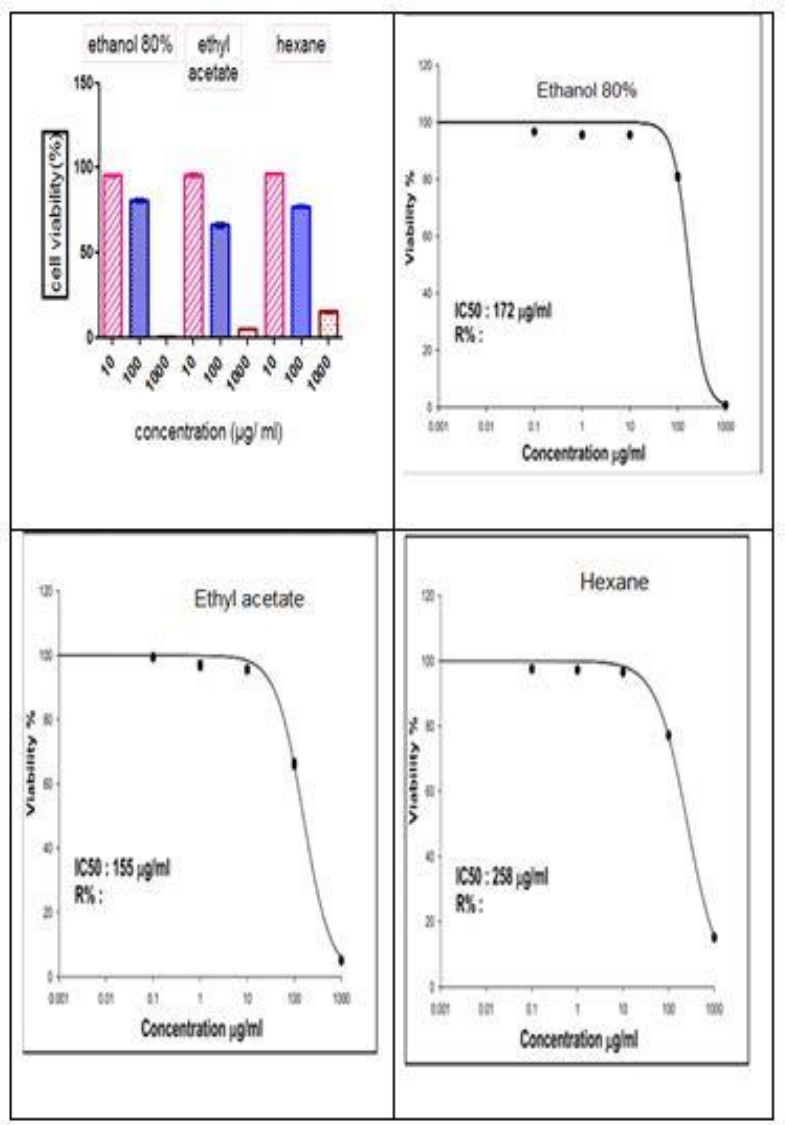

Figure (3) : Effect of C. citratus extracts (Ethanol, Ethyl acetate and Hexane) on Human breast cancer(MCF-7) cell viability by the SRB assay. The data were expressed as Mean \pm SD of separated triplicate experiments.

\section{Discussion}

Cancer cells survive by several molecular signaling pathways. Therefore, chemo-preventive agents must successfully influence different signaling pathways as compared to targeting just one pathway. Cancer chemoprevention needs the cooperation of multidisciplinary groups to find target specific and less toxic agents to block, retard, or reverse the carcinogenic process. Since lemongrass is an aromatic grass that yields an essential oil used in pharmaceutical industries and treatment of different diseases as an alternative traditional medicine [1].

This result found that autophagy was significantly $(\mathrm{P} \leq 0.05)$ increased in treated HepG2 cells as compared to non-treated cells. The present data suggested that combined treatment with cinnamon and lemongrass aqueous extracts can exert an anticancer effect through induction of apoptosis, autophagic cell death activation, and inhibiting cell proliferation in HepG2 cells [20].

Hence, the result indicates that the concentration of phytochemicals in the different extracts plays a vital role in cytotoxicity. The previous study supports the findings of this study, that citral inhibits P388 mouse leukemia cells and oil from Cymbopogon flexuosus induced differential in vitro cytotoxicity in 12 human cancer cell lines and in vivo tumor growth inhibition in murine, Erlich and S-180 tumor models [21].

This result indicated that $C$. citratus essential oil (LEO) from Cymbopogon citratus on A549 cell line and their effect on the expression of p53 gene in lung cancer cells. The LEO was extracted and anlaysed using GC-MS analysis, the cytotoxicity of LEO against lung cancer cells was examined using MMT assay and finally the expression of p53 was determined via qRT-PCR. The chromatogram of GC-MS exhibited 14 compounds in ELO, the major one is citral (56.4\%). The cytotoxicity of LEO was dose dependent which proliferation of the lung cells were significantly inhibited with increased concentration of essential oil $(\mathrm{P} \leq 0.01)$ as well as the $\mathrm{IC}_{50}$ was $29.13 \mathrm{ppm}$. Furthermore, it showed that cell treated with $\mathrm{IC}_{50}$ of LEO had a significant higher gene expression $(\mathrm{P} \leq 0.05)$ in the fold of $\mathrm{p} 53$ expression than untreated cells with change fold of $4.47 \pm 0.7$ [22].

This result found that The IC 50 mean values obtained by the neutral red assay were 600 and $630 \mu \mathrm{g} / \mathrm{ml}$ for CWE and $\mathrm{LgWE}$ respectively. The lower value of IC 50 indicates the greater antioxidant activity. Cinnamon has cytotoxic effect on HepG2 cells more than that of cinnamon more than that of lemongrass [23].

This results showed that essential oil of lemon grass possessed potential cytotoxic effect on HCT-116 and with the IC ${ }_{50}$ value of $27.41 \pm 4.3 \mu \mathrm{g} / \mathrm{mL}$ comparing to MCF-7 with IC 50 value of $41.90 \pm 1.2 \mu \mathrm{g} / \mathrm{mL}$. Significant anti angiogenic activity of the sample was observed with $99 \pm 0.8 \%$ of inhibition at $100 \mu$ $\mathrm{g} / \mathrm{mL}$, the lemon grass essential oil showed promising activity on the cytotoxicity against colorectal carcinoma cell line. Thus, bioassay guided fractionation will be conducted to determine the active compound against the colorectal cancer cell line growth[24]. 
This result C. citratus showed high contents of total phenolic and total flavonoids, as well as high free radical scavenging capacity with potential as an antioxidant. C. citratus shows good antiinflamatory, anti-diabetic, hypolipidemic, renoprotective and cardioprotective, as well as anticancer activities. Apart from this, C. citratus possesses vasorelaxant, sedative and antitusive potential. Furthermore, the compound citral is used in perfume industry as well as for cleaning wounds and treatment of skin diseases in forms of gels, or functional paper microencapsulated with essential oil, which can be used for hand hygiene [25].

\section{Statistical analysis:}

Experimental results were means \pm SD of three parallel measurements. Analysis of variance was performed by One Way ANOVA procedures. Graphpad prism ${ }^{\circledR}$ was used for statistical calculations Graphpad software, San Diego, CA, USA [26].

\section{Conclusions}

In this present study, we evaluated the anticancer effect of different extracts of lemongrass plants (ethanol, ethyl acetate, and hexane) on cervical cancer cell lines (A549, HepG2, and MCF-7) in vitro. Lemongrass ethyl acetate fraction treatment (24 $\mathrm{h}$ incubation) significantly decreased the percentage of cell viability in A549, HepG2, and MCF-7 cells. This suggested that Ethyl acetate extract showed the highest anticancer activity against A549, HepG2, and MCF-7 human cancer cells with cell viability percentage $(64.09 \pm 1.11,41.22 \pm 0.34$, and $66.24 \pm$ $1.50 \%$, respectively) with $\mathrm{IC}_{50}$ values $(147,65$, and $155 \mu \mathrm{g} / \mathrm{ml}$, respectively).

\section{References}

[1] Lewinsohn, E., Dudai, N., .Tadmor, Y. Katzir, I., Ravid, U. Z. I., Putievsky, E. L. I., and Joel, D. M. Histochemical localization of citral accumulation in lemongrass leaves (Cymbopogon citratus (DC.) Stapf., Poaceae)," Annals of Botany, 1998, v. 81,(1), pp. 35-39.

[2] Vinitketkumnuen, U., Puatanachokchai, P., Kongtawelert, P., Lertprasertsuke, $\mathrm{N}$ and Matsushima, $\mathrm{T}$. Antimutagenicity $\mathrm{Of}$ lemongrass (Cymbopogon citratus Stapf) to various known mutagens in salmonella mutation assay," Mutation Research Genetic Toxicology, 1994, v. 341.( 1), pp. 71-75.

[3] Santoro, G. F., Cardoso, M. G., Guimaraes, L. J. L., Freire, J. M. and Soares, M. J. Anti-proliferative effect of the essential oil of Cymbopogon citratus (DC) Stapf (lemongrass) on intracellular amastigotes, bloodstream trypomastigotes, and culture epimastigotes of Trypanosoma cruzi (Protozoa: Kinetoplastida), Parasitology, 2007, v. $134,(11)$, pp. 1649-1656.

[4] Viana, G. S. B., Vale, T. G., Pinho, R. S. N. and Matos, F. J. A. Antinociceptive effect of the essential oil from Cymbopogon citratus in mice,"Journal of Ethnopharmacology,2000, v. 70, ( 3), pp. 323327.

[5] Santin, M. R., dos Santos, A. O., Nakamura, C. V., Dias Filho, B. P., Ferreira, I. C. P. and Ueda-Nakamura, T. In vitro activity of the essential oil of Cymbopogon citratus and its major component (citral) on Leishmania amazonensis," Parasitology Research, 2009, v.105, (6), pp. 1489-1496.

[6] Oliveira,V. C., Moura, D. M., Lopes, J. A., de Andrade,P. P., da Silva, N. H. and Figueiredo, R. C. Effects of essential oils from Cymbopogon citratus (DC) Stapf., Lippia sidoides Cham.,and Ocimum gratissimum L. on growth and ultrastructure of Leishmania chagasi promastigotes," Parasitology Research, 2009, v,104, (5), pp. 1053-1059.
[7] Carlini, D. D. E., Contar, A. R., Silva-Filho, N. G., da SilveiraFilho, M.L. Frochtengarten and Bueno, F. O. lemongrass (Cymbopogon citratus Stapf). I. Effects of teasprepared from the leaves on laboratory animals. J. Ethnopharmacology, 1986, v. 17, (1), pp. 37-64.

[8] Cheel, C. J., Theoduloz, J., Rodr'iguez, and SchmedaHirschmann, G. Free radical scavengers and antioxidants from lemongrass (Cymbopogon citratus (DC.) Stapf.)," J. Agricultural and Food Chemistry, 2005, v. 53, (7), pp. 2511-2517.

[9] Roopashree, R., Mohan, C. D., Swaroop, T. R., Jagadish, S. and Rangappa, K. S. Synthesis characterization and in vivo biological evaluation of novel benzimidazoles as potential anticancer agents. Asian J Pharm Clin Res, 2014, 7, PP.309-13.

[10] Block, T. M., Mehta, A. S., Fimmel, C. J. and Jordan, R. Molecular viral oncology of hepatocellular carcinoma. Oncogene, 2003, 22, (30), PP.5093-5107.

[11] Mikhaeil, B. R., Badria, F. A., Maatooq, G. T. and Amer, M. M. Antioxidant and immunomodulatory constituents of henna leave. Naturforsch C: Biochem Biophys Biol Virol, 2004, 59:PP.468-476.

[12] Stewart, B. W. \& Wild, C. (2014). World Cancer Report International Agency for Research on Cancer, WHO Press, Lyon, France.

[13] Gadepalli, S. P., Deb, S., Deb, \& Rao, R. R. Lung cancer stem cells, p53 mutations and MDM2," Subcellular Biochemistry, 2014, v. 85, pp. 359-370.

[14] American Cancer Society. Breast Cancer Facts \&Atlanta, GA: American Cancer Society, 2017.

[15] Bruix, J., and Sherman, M. Management of Hepatocellular Carcinoma. Hepatology, 2005, 42(5):PP.1208-1236.

[16] Anwar, W. A., Khaled, H. M., Amra, H. A., El-Nezami, H. and Loffredo, C. A. Changing pattern of hepatocellular carcinoma (HCC) and its risk factors in Egypt: possibilities for prevention. Mutat. Res., 2008, 659(1-2): PP.176-184.

[17]Fitrotunnisa , Q., Arsianti , A., Tejaputri . N.A. and Qorina. F. Antioxidative Activity And Phytochemistry Profile Of Hibiscus Sabdariffa Herb Extracts. . 2019, Int J. App Pharm, V. 11, 29-32 .

[18] Allam, R. M., Al-Abd, A. M., Khedr, A., Sharaf, O. A., Nofal, M S., Khalifa, E. A., Mosli, A. H. and Abdel-Naim, B. A. Fingolimod interrupts the cross t.alk between estrogen metabolism and metabolism within prostate cancer cells. Toxicology Letters, 2018, 11, (291), PP.77-85.

[19] Skehan, P., Storeng, R., Scudiero, D., Monks, A., McMahon, J., Vistica, D., Warren, T. J., Bokesch, H., Kenney, S. and Boyd, R. M. New colorimetric cytotoxicity assay for anticancer-drug screening. J. Natl Cancer Inst ,1990, 82(13):PP. 1107-1112.

[20] El-Nabi, S. H., El-Garawani, I. and El-Berry, A. The Apoptotic Properties Of Cinnamomum Zeylanicum and Cymbopogon Citratus On Human Hepatocellular Carcinoma Cell Line (Hepg2). Europ. J. of Pharm. and Med, Res. ejpmr, 2016,3(9), 44-48.

[20]Sobhy, H.; Islam, El. and Aya, El. Implications of combination treatment with aqueous extracts of cinnamon and lemon grass on human hepatocellular carcinoma (HepG2) cell line. J. Exp. Biol. (Zool) 2017. 13(2): $139-148$.

[21] Dubey, N. K., Kishore, N., Varma, J. and Lee, S. Y. Cytotoxicity of the essential oil of Cymbopogon citratus and Ocimum gratissimum. Indian J Pharm Sci. 1997, 59, (5): PP.263-264.

[22]Abdulhasan, G. A. Lemongrass Essential Oil Shows An Antiproliferative Effect On Lung Cancer Cells and Its Role In Expression Of P53 Gene. Iraqi J. of Agric. Sci: 2021, 52(2):359-366. [23] El-Nabi, S. H., El-Garawani, I. and El-Berry, A. The Apoptotic Properties Of Cinnamomum Zeylanicum and Cymbopogon Citratus On Human Hepatocellular Carcinoma Cell Line (Hepg2). Europ. J. of Pharm. and Med, Res. ejpmr, 2016,3(9), 44-48

[24] Piaru, S. P., Perumal, S., Cai, L. W., Mahmud, R., Abdul Majid, A. M. S., Ismail,S. and Man, C. N. Chemical composition, antiangiogenic and cytotoxicity activities of the essential oils of Cymbopogan citratus (lemon grass) against colorectal and breast 
carcinoma cell lines. The J. of Essential Oil Res. 2012, V. 24, N. 5. $453-459$.

[25] Aćimović, M., Čabarkapa, I., Cvetković, M., Stanković Jeremić, J., Kiprovski, B., Gvozdenac, S., and Puvača, N. Cymbopogon citratus (DC.) Staph: Chemical composition, antimicrobial and antioxidant activities, use in medicinal and cosmetic purpose. $J$. of Agronomy, Technology and Engineering Management (JATEM), 2019, 2(6), 344-360.

[26] Motulsky, H. J. Analyzing Data with Graphpad prism, Graphpad software Inc., San Diego CA, 1999, WWW. Graphpad. Com 